\title{
ENGLISH TEACHERS' PERCEPTIONS OF STUDENT EVALUATION OF TEACHING IN AN INDONESIAN UNIVERSITY
}

\author{
Rentauli Mariah Silalahi \\ (rentauli@del.ac.id) \\ Institut Teknologi Del \\ Jl. Sisingamangaraja, Sitoluama, Laguboti, \\ Toba Samosir, Indonesia,22381
}

\begin{abstract}
Student evaluation of teaching (SET) has been proven to improve teachers' teaching practices and students' learning experiences despite being used commonly for accountability purposes. Indonesian teachers' perceptions of SET, however, remain largely unexplored. This qualitative study therefore investigated how four Indonesian university teachers perceived SET, how SET impacted their teaching practices and what roles they believed the university should play in implementing SET properly. The participants taught English to undergraduate students in an Indonesian private university. Data were collected using semistructured interviews and analysed using qualitative methods. The teachers perceived SET positively, had made conscious changes to improve their teaching practices and students' learning, and believed the institution had facilitated teachers in meeting students' needs, especially during the campus closure due to the COVID-19 pandemic, which led to a transition to online learning. The institution where the participants taught implemented SET only for formative or improvement purposes. Using SET for such purposes is important as it is more likely to cause teachers less pressure and anxiety. Hence, teachers are willing to act upon the student feedback. Meanwhile, using SET for accountability purposes may create extra work for teachers and make them feel manipulated and untrusted.
\end{abstract}

Keywords: accountability, improvement, student evaluation of teaching, student feedback, teacher evaluation

DOI: http://dx.doi.org/10.15639/teflinjournal.v32i2/316-341 
Evaluation is key to quality assurance in higher education. Its outcomes reflect an institution's performance and accountability (Kai, 2009). However, 'quality' is an elusive, value-laden concept, and people may perceive quality differently according to their beliefs about what 'good' means (Green, 1994). Therefore, various stakeholders may define 'quality higher education' differently depending on their purposes and objects of evaluation (Dicker et al., 2019; Green, 1994). For example, students may believe a quality higher education institution should employ caring academics who can build good relationships with students, while employers may believe a quality higher education institution should produce competent and skilful graduates who are motivated and disciplined.

Responding to the complexity in defining quality, Harvey and Green (1993, p. 3) proposed that quality in higher education "can be viewed as exceptional, as perfection (or consistency), as fitness for purpose, as value for money and as transformative.' These dimensions become important assessment criteria for implementing quality control and monitoring in higher education (Harvey \& Newton, 2004). Scheerens et al. (2003) argued that quality monitoring and evaluation take three forms: accreditation, accountability and improvement. While accreditation and accountability concern the quality dimensions of exceptional, perfection, fitness for purpose, and value for money, improvement concerns the dimension of transformative (Harvey \& Newton, 2004).

As interest in teacher quality increases, teachers have become objects of scrutiny; they are frequently monitored and evaluated for improvement or accountability purposes. Generally, when the objective is improvement, teachers feel excited about teaching assessments; however, when the objective is accountability, teachers feel stressed. While teachers may be assessed by students, peers or superiors, this study focuses on students' evaluation of teachers' effectiveness, also known as student evaluation of teaching (SET).

SET became popular in the 1970s when an increasing number of universities used SET for summative evaluations such as tenure and promotions (Hornstein, 2017; Spooren \& Mortelmans, 2006). Since then, many universities have considered it necessary to assess teachers' instruction quality using SET (Kember et al., 2002). In addition to summative assessments, SET is useful for improving teaching practices (OECD, 2009) and has become the preferred tool in higher education for evaluating teachers' effectiveness (Hedges \& Webber, 2014). Many institutions have been using SET for teacher appraisal, collecting data that are important for teachers' self-reflection and teaching improvement 
and providing students with information before choosing a course (Kember et al., 2002; Marsh \& Roche, 1993). Countries that commonly implement SET for improvement or accountability include the US, UK, Canada and Australia (Hammonds et al., 2017; Hornstein, 2017; Neumann, 2000; Richardson, 2005; Shevlin et al., 2000).

Countries may use different terms for their SET. For instance, in the UK, SET is called the National Student Survey (NSS) and is implemented nationally (Richardson, 2005). Meanwhile, Australia uses the Student Evaluation of Teaching Subjects (Neumann, 2000). Despite these differences, SET requires students' honest and constructive feedback. Students are expected to provide constructive criticisms of instructors' teaching effectiveness. However, teaching effectiveness (Kulik, 2001) and SET (Shevlin et al., 2000) are multidimensional. Thus, different stakeholders may evaluate effective teaching differently. For instance, students may consider an effective teacher one who gives students less challenging assignments and tests, while teachers may hold the opposite view (Yao \& Grady, 2006). Teachers' beliefs about effective teaching are based on their knowledge of pedagogy (Hornstein, 2017), and, considering the knowledge gap between students and teachers, teacher discretion is always required when responding to student feedback (Yao \& Grady, 2006).

Teachers may respond to SET in various ways, which corresponds to their perceptions of SET. For instance, some teachers might perceive SET positively while others perceive it negatively. Factors that influence teachers' opinions include using SET for purposes other than teaching improvement, such as for career decisions, awards, teaching allocation and accreditation (Kulik, 2001). Another factor is their beliefs about the credibility of SET and students as assessors. Teachers who believe that SET is credible and employed with good intentions regard SET positively (Seldin, 1997). Moreover, acknowledging students' ability to identify learning problems that teachers may overlook shapes teachers' positive views (Ballantyne et al., 2000). Consequently, teachers with positive attitudes are optimistic about changing their teaching practices such as found in New Zealand (Spiller \& Ferguson, 2011) and Sweden (Flodén, 2017). Optimistic teachers modify their teaching practices to meet students' needs by, for example, 'modifying the teaching material, increasing academic depth, supporting multiple skill levels through a variety of activities, introducing a different assessment' (Arthur, 2009, p. 449), 'using more visual material, putting 
more of an emphasis on course objectives, or allocating marks differently to coursework' (Moore \& Kuol, 2005, p. 66).

Conversely, teachers who have negative perceptions of SET question its credibility. They doubt students' ability to evaluate their teaching effectiveness, believing that students may be biased (Emery et al., 2003) and lack understanding of the course materials (Arthur, 2009). Interestingly, some studies confirm that students display biases while evaluating their instructors' teaching effectiveness. Factors that affect student biases include 'self-reported GPA, expected grade, course level, department, class size, class timing, and student gender' (Badri et al., 2006, p. 52), as well as teachers' gender (Boring, 2016), characteristics and charisma (Hornstein, 2017; Shevlin et al., 2000). Nevertheless, student bias should not be generalised, as different contexts may yield different results. For instance, Zabaleta's (2007) study of one Spanish university found no biases in students' SET feedback.

Another factor that influences teachers' negative perceptions of SET is how the SET results are used, as using SET for summative purposes can place a great psychological burden on teachers. Negative feedback often leads to pain and shame for teachers, as their professional reputations are at stake (Arthur, 2009). To garner positive feedback from students, teachers sometimes act improperly by lowering grading standards (Krautmann \& Sander, 1999), 'watering down...course content, grade inflation, and decreas[ing] exam difficulty' (Murray, 1987, p. 6). Such misconduct may harm teachers' professionalism and students' education.

Considering the significant impact of receiving negative feedback on teachers' professionalism and wellbeing, teachers need support. Supporting teachers involves ensuring their confidentiality and giving them ownership of the feedback collected from SET (Cohen \& Mays, 1981). Further, the university can support teachers by providing expert consultations, which is effective at helping teachers improve their teaching practices (Kulik, 2001; Murray, 1987). Moreover, giving teachers ownership of the feedback and the autonomy to decide which issues are crucial and require follow up is necessary for teachers' comfort (Marsh \& Roche, 1993).

Thus far, teachers' perceptions of SET have been investigated using qualitative, quantitative, and mixed-method research designs. Conducting qualitative studies in different settings, Ulker (2021) and Alsabahi (2020) found rather similar findings. Ulker's (2021) study was conducted in a Turkish and an 
American university while Alsabahi's (2020) study was conducted in a Saudi Arabian university. Through interviews, both studies found that teachers were not involved in the design of the SET contents and that the universities did not provide support for teachers to interpret the SET results. Further, while some teachers believed that students could give a valid evaluation of teachers' classroom teaching effectiveness, other teachers feared that students might be biased, hence doubted the students' ability to give sincere evaluation. The teachers also raised concerns over students' increasingly low response rate on the SET and the use of SET results for summative purposes such as for promotion, tenure, and salary. Both studies also found that teachers considered it important to provide students with enough information about the importance of SET and to give students training on it. Suggestions about how to respond to SET results come from another qualitative study conducted by Cain et al. (2019). Interviewing nine pharmacy instructors in an American institution, Cain et al. found that the teachers recommended using discretion to respond to SET results and considered the SET results as a reflection on their teaching practices.

The emphasis on using the SET results for formative purposes such as in Cain et al.'s (2019) study is also found in some other quantitative studies. For example, collecting data using surveys, Debroy et al. (2019), Yusuf et al. (2010), Iyamu and Aduwa-Oglebaen (2005), and Beran and Rokosh (2009) found that teachers perceived SET results as valuable resources to improve their instruction and help students learn better. Yet, like Ulker's (2021) and Alsabahi's (2020) studies, Debroy et al.'s (2019) study investigating ten medical education instructors in India found that the teachers still considered students as biased regarding teachers' different characteristics, hence recommended peer review as a better option to evaluate teacher's teaching effectiveness. Meanwhile, from investigating 326 teachers from three Nigerian universities (Yusuf et al., 2010) and 200 teachers from five Nigerian public universities (Iyamu \& AduwaOglebaen, 2005) using a questionnaire called the Lecturers Response to Students Evaluations of Teaching (LRSET), Yusuf et al. (2010) and Iyamu and AduwaOglebaen (2005) found that junior teachers perceived SET as threatening. Junior teachers often felt pressured to achieve good SET results, as the results are used to determine their career progression; that means, the teachers felt, that negative student feedback could put an end to their work contracts. Meanwhile, senior teachers' careers were not impacted by SET results because they had already earned tenure. 
Further, other quantitative studies found an issue regarding the confidentiality of the SET results. Nasser and Fresko (2002) found that teachers in an Israeli university felt disappointed at having their SET results distributed to colleagues and students while Beran and Rokosh (2009) found that teachers in a Canadian university felt disappointed with the university's policy of disseminating SET results to the public. Interestingly, using an online survey, Kogan et al. (2010) found that SET feedback emotionally impacted female teachers more than male teachers. These female teachers suffered from distress, shame, and anger after receiving negative student feedback.

While Kogan et al.'s (2010) study found that female teachers are more deeply impacted from SET feedback, Lynch's (2019) mixed-method study found that SET results can impact all teachers emotionally despite gender. Surveying 20 teachers and interviewing three of them, Lynch (2019) found that the teachers in Sweden have mixed perceptions of the SET results. While some teachers found the results useful to improve their teaching practices, others found the results less credible hence preferred collecting student feedback directly in their classes. These findings are rather similar to the findings of Chan et al.'s (2014) mixed-method study investigating science teachers in Hong Kong. Chan et al. found that teachers who perceived SET negatively considered students less capable of evaluating teaching effectiveness. These teachers claimed students gave negative feedback when the students lacked interest in the course or considered the course too difficult. Meanwhile, the teachers who perceived SET positively believed that SET results accurately reflected teachers' teaching quality and ability. Teachers' positive attitude towards SET may also come from teachers' belief in students' ability to assess teaching. For example, collecting data from questionnaires and interviews in a Kenyan university, Maiyo (2020) found that teachers believed their students to be valid assessors of teaching effectiveness. However, lacking communication may cause teachers to have a negative attitude towards SET as found in Wong and Moni's (2014) mixedmethod study. Wong and Moni found that teachers were disappointed with the lack of information about the purpose and implementation of SET in their institution. Consequently, the teachers paid little attention to the programme and made no effort to act upon their SET results.

Despite the extensive discussion on SET in the extant literature, exploration of Indonesian teachers' perceptions of SET is still rare. This study intends to address this gap. Understanding teachers' experiences and challenges may add 
richness to the rationales behind teachers' perceptions on how SET may impact their teaching practices. Therefore, this study was conducted using the qualitative method of interviewing Indonesian teachers; all the teachers were English teachers at a single Indonesian private university.

In Indonesia, universities design and implement their own SET surveys because there is no standardised national SET like the UK's NSS (Richardson, 2005). When an Indonesian university collects student feedback, the data collected from the SET surveys are commonly used for external quality assessments such as accreditation, similar to the UK context where quantitative data from SET can be used for external quality assessment (Coffey \& Gibbs, 2001). According to the accreditation guidelines, teachers should attempt to respond to student feedback and review the results after implementing changes (BAN-PT, 2019). However, Indonesian university teachers often feel pressured while performing their duties because they are overloaded with administrative work, teaching and researching (Gaus \& Hall, 2016).

Teachers may be stressed by their workloads while also coping with pressures from receiving student feedback. Thus, it is important to investigate teachers' perceptions of SET. After all, SET results can only be useful when teachers act upon them. In Indonesia, teachers' perceptions of SET are rarely studied. Therefore, this study investigates Indonesian university teachers' perceptions of SET, focusing on English teachers. This study aims to answer the following questions:

1. What are the English teachers' perceptions of SET?

2. How does SET impact the English teachers' professional teaching practices and career?

3. What roles do the English teachers believe the institution should play in the implementation of SET?

\section{METHOD}

This study was conducted in an Indonesian private university in North Sumatera during October 2020 by recruiting the university's English teachers, who the researcher knows well. Hence, the participants were recruited using a convenience sampling method that allowed for convenient, simple, and relatively inexpensive recruitment (Tracy, 2013). The institution employs six English teachers who instruct undergraduate students; however, only four 
volunteered to be interviewed. The teachers were interviewed over the telephone due to the COVID-19 restrictions that limit people's mobility and face-to-face interaction. After all, the telephone interview is convenient, inexpensive and can be administered quickly (Bryman, 2008). Considering the participants are English teachers, the interviews were conducted in English and lasted around 30 to 45 minutes. The semi-structured interviews were recorded with participants' consent and were transcribed verbatim afterwards. The semi-structured interview gives the interviewer the flexibility to develop discussion topics organically while remaining focused on the issues under investigation (Bryman, 2008). Pseudonyms are given to all participants for confidentiality purposes (Tracy, 2013).

All of the participants hold a master's degree in English education; three graduated from Australian universities, and one graduated from an Indonesian university. Two of the teachers, Tony and Jane, have only worked in the institution for less than two years, while the other two, Martha and Susan, have worked in the institution for more than four years. The teachers' age is between 30 to 40 years old.

Exploring the teachers' subjective views of SET and interpreting their views are essential to answering the research questions. Therefore, this study uses an interpretivist paradigm. As an interpretivist, the author believes there are multiple realities, and each interviewee perceives reality differently (Usher, 1996). The interpretivist paradigm allows the author to seek in-depth information about each teacher's perception of SET and their experiences with SET results. Thus, interviews are the best method to collect the data.

For respondent validation (Tracy, 2013), the participants were given transcripts of their interviews for confirmation, ensuring that the author captured their statements correctly. For triangulation, the author compared the participants' views with evidence from related literature. Before the interview, the author obtained ethical approval from the participants' institution and consent from the participants.

The data was analysed following Miles and Huberman's (1994) qualitative data analysis, which involves three main components: reducing the data, displaying the data, and drawing and verifying a conclusion. Throughout the analysis, the author coded and wrote memos. The coding process involved not only descriptive coding but also pattern coding, enabling the author to interpret data that best reflects the participants' experiences. All the excerpts presented in 
this paper were quoted verbatim from the interviews. During the analysis, the author identified important themes related to the research questions, as discussed in the following section.

\section{FINDINGS AND DISCUSSION}

This section presents the findings from the data analysis, which reveal the English teachers' perceptions of SET. The results are presented following the research questions' major issues: the teachers' perceptions of SET, the impacts of SET on the teachers' teaching practices and careers, and the teachers' views on the institution's roles in implementing SET.

\section{English Teachers' Perceptions of SET}

The analysis revealed that all the four teachers perceived SET positively despite the possibility of receiving negative feedback. The teachers' positive perceptions indicate that they are open-minded. According to Huisman and Currie (2004), being open-minded and motivated to improve oneself helps shape teachers' positive attitudes. Unlike the female teachers in the study by Kogan et al. (2010), the three female teachers in the current study were open to negative feedback.

The fundamental reason for the teachers' positive attitudes was their belief that student feedback is important to help them reflect on their teaching and make necessary improvements (Cain et al., 2019). This belief aligns with Maiyo's (2020), Ulker's (2021) and Alsabahi's (2020) findings that teachers' positive views of SET are based on their belief that students have the ability to assess their teaching effectiveness and Ballantyne et al.'s (2000) finding that teachers appreciate and recognise students' ability to identify learning problems that teachers may overlook. In this study, a comment from Tony, the only male teacher interviewed, may represent the positive perceptions of all the English teachers participating in the study:

I am very open to criticism because I think it's good for self-improvement. Without criticism, without evaluation, we don't know where to go in the future, what to improve. So, I would be open to student feedback of the teaching.... and I like that feedback. 
Furthermore, the teachers seemed to prepare themselves to receive either positive or negative feedback. This is quite uncommon, as, in other places, teachers often attempt to avoid receiving negative feedback that causes them pain and shame. This study found that the teachers regard positive feedback as motivation to continue improving their teaching practices, while they regard negative feedback as an opportunity to reflect on their weaknesses. Jane, one of the female teachers, mentioned how she sometimes looks forward to negative feedback, which allows her to identify her teaching weaknesses and ensure that students are engaged during class:

[To] some extent, I can be excited. I can get to know how well or how bad I have been doing. But, [to] some extent, I can be nervous because...it could be bad, it could be good, you know. But most of it feels good. I mean, [whether] it is good or not, it is needed for improvement. But, by giving specific feedback, either good or bad, then it is one indicator for the teacher that your students are paying attention. If you are open-minded, I think there is nothing wrong [with] negative feedback as long as it is justifiable. I mean, I look forward to negative feedback sometime[s] so [I] know what is happening with my teaching.

Other teachers expressed similar perspectives:

So, if I receive good evaluation[s] from students, I will be motivated. It is not just [a] compliment to me, but motivation to teach better in the next semester. But, if I have bad comment[s] from students, it is a reminder to me that I need improvement. So, I will think of other methods to teach the students in the next semester so that they can understand the lessons. (Susan)

I think, I would say I feel excited about having student feedback because, that way, I would say I know what is good and what is not good about my teaching - what I need to improve. I don't mind...the student evaluation, because sometimes I am actually the one who ask[s] for their evaluation. (Martha)

In these cases, the teachers likely felt no shame or pain from receiving negative feedback, unlike the teachers in Arthur's (2009) study. Meanwhile, Martha, another female teacher, specifically mentioned how students' constructive feedback could provide valuable information for teachers to keep themselves abreast of new teaching methods and technology. It reflects Lynch's (2019) findings that teachers find the SET results useful for improvement. Martha's statement emphasises that teaching is a dynamic profession due to the development of new technologies, teaching methods and tools: 
The teaching itself is dynamic. I think I need evaluation from people [to] mak[e] my teaching better and improve myself, and...I think it is also a way for me to keep updated with my teaching style.

Another reason for the teachers' positive attitudes is their confidence that the students and the assessment tools are credible. The participants believe that students are capable of assessing their teaching effectiveness, although they also acknowledge that students may display biases due to the nature of human subjectivity. Still, they do not feel those biases significantly impact the SET because they believe the assessment tool is credible and can control student bias. These findings align with Seldin's (1997) finding and Sofyan et al.'s (2021) study of SET in Asian higher education context that teachers' confidence in the tool's credibility shapes their positive perceptions of SET.

All of the participants expressed that the current wording of the questionnaire items made the SET credible. The teachers recommended that the questions focus on the teaching and learning process, the lessons learned, and the students' experiences throughout the teaching and learning process. In contrast, questions asking students to assess a teacher's personality or compare different teachers should be avoided, as they are highly subjective. Interviewees offered examples of problematic questions:

Is the teacher good in your class? (Susan)

Are the teachers generous in giving scores? (Jane)

Which one do you like, Ms Y or Mr X? (Martha)

The interviewees also commented on students' ability to assess teaching effectiveness:

I think the students are able to answer the questions because the students I taught know whether they understand the course I gave them or not. And then, I think that depends on the questions given to the students. But, for the questionnaire given to the students, I think they can answer that very well. It just reflects the condition of each course in each semester. (Susan)

They are the ones that I teach, so I think they are credible because they see me in person. They know how I am teaching. (Jane)

I think they are the right persons to ask about my teaching, especially the weakness[es], because they are the ones [who] experience my teaching. They face me like every week. They know whether I do the preparation or not. They are actually the ones who are supposed to give [the] evaluation to me not, like if you 
are mentioning, [an] observer in a class. An observer is someone coming to your class, observing your class occasionally. Then probably you can do [your] best at their coming, but the students will be there all the time, right. So, I think they will be the right persons to give evaluation not the external party coming to your class occasionally. (Martha)

Martha's final comment brings up the issue of credibility when a teacher is evaluated by an external party. However, there may be issues with peer observation apart from the observer's credibility (OECD, 2009). As Martha said, there could be issues of the representativeness of a teacher's overall teaching quality, as the teacher may prepare excessively to perform well during a onetime observation. Nevertheless, when SET is used for accountability purposes, other evaluation methods, such as observation and peer review, may be necessary to complement the SET results. Observation and peer review can provide a more robust evaluation of a teacher's quality, as peers offer different perspectives from students, such as providing expert opinions on the teaching materials (Hornstein, 2017).

\section{The Impacts of SET on English Teachers' Teaching Practices and Career}

SET can impact teachers in many ways. However, in this study, the English teachers described similar experiences of how student feedback affects their professional development. They felt it contributes greatly to advancing their teaching methods and student-teacher relationships. As Ory (2000) suggested, teachers can perceive evaluations as a means and opportunity for self-reflection (Cain et al., 2019), dialogue and discussion (Alsabahi, 2020). SET is effective at improving teaching quality so long as teachers act upon student feedback (Grimard et al., 2018; Hendry \& Dean, 2002).

The most important function of student evaluations in this particular institution is to enable teachers to reflect on and improve their teaching practices. As professionals, teachers should commit to learning throughout their careers (Arthur, 2009) and be reflective to improve their teaching, skills and student outcomes (Hendry \& Dean, 2002).The English teachers in this study demonstrated their commitment to their professional responsibilities by continually improving their teaching effectiveness.

For example, Tony mentioned that, as a result of student feedback, he has made his slideshows more colourful: 
After receiving student feedback, of course, I think about their comments, so I made some changes to my teaching. [If] their comments... are acceptable and thoughtful, then...I will make some changes. Let's say, for example, I made my slides more colourful now... that is an example that I have made in my teaching.

Meanwhile, student feedback encouraged Susan to change her teaching method, allocating fifteen to twenty minutes of class time to check students' understanding:

So, fifteen minutes or twenty minutes before the class, I checked the student[s'] understanding, something like post-test, like what they understand about the course. For example, a question like 'what do you understand about this text?' So, instead of just giving them [an] assignment or exercise, I think that it will be more effective to know immediately whether the student[s] have understood the lesson or not.

Susan's new approach helps ensure that students understand the lesson and allows quiet students to tell the teacher about their learning difficulties.

Teachers also adjusted their use of English in the classroom. For example, Jane now slows her pace when speaking English to help students understand her. When necessary, she also uses the Indonesian language to clarify the meaning of important terms:

When they said that I speak too fast, then I changed my way of speaking. I speak more slowly. And when they said that I need to speak in Bahasa Indonesia or even in mixed language when I talk about technical terms that they don't understand basically, then I do so. I mean, it's not that I am showing off my English in front of my students. My purpose is to make them able to understand the lesson. So, I think, going [at] their pace, I hope that can help them. Because, you know, this online learning is already hard, so why [not] try to make that easy for them?

While Jane responded to student feedback to use the local language for clarity, Martha, one of the senior teachers, took the opposite approach. Martha objected to using the local language based on her claim that she had adjusted her spoken English to students' level of English proficiency:

Well, obviously, this is an English class, and, because they are intermediate to upper-intermediate students, then I would know that they are quite advance[d] in English, so I would say to them, 'Well, if you are asking me to use Bahasa Indonesia in the class, this class should be changed into Indonesia[n] class than English class. 
This shows that teachers must use their discretion to make sensible changes to their teaching practices (Yao \& Grady, 2006). Jane believed that the changes she made might help lessen students' anxiety over the challenges of learning during the pandemic. Jane's willingness to change to create better learning circumstances concurs with findings from Spiller and Ferguson (2011) and Flodén (2017).

The teachers also mentioned that collecting and acting upon student feedback made the students more open about their difficulties understanding the lessons. The teachers' efforts are important to strengthening the student-teacher relationship (Sofyan et al., 2021). Clearly, the teachers understood that 'the heart of the education service is the relationship between the lecturer and student in the teaching and learning process' (Green, 1994, p. 16). After all, education aims to continuously improve students' learning and experiences (Mertens \& Prosser, 1998) and empower students to be life-long learners (Harvey \& Knight, 1996). In their responses, the teachers implied that they care about their students' experiences and strive to provide the best learning experiences possible:

I think, when you try to be open, the students will be open too. So, I think that is how you connect yourself to students and get more feedback. So, I am trying to maintain [a] good relationship with my students by being open, being open-minded and negotiable. You know, how to motivate them to be open and speak more. (Jane)

Our relationship is getting stronger. You know, they say what their feelings are, and some make sense. I think that is something good for my betterment. Then, I would make my teaching better, and it would make them happy, and I think that is a better relationship. (Martha)

\section{English Teachers' Perceptions of the Institution's Role in Implementing SET}

The teachers shared that the institution collects SET surveys for improvement purposes only. These surveys do not determine decisions related to the teachers' careers, so teachers are not unduly stressed by the results of student feedback. Using SET results for formative purposes only may contribute to the teachers' positive perceptions since they have no fear of losing their jobs. Teachers at this institution face no negative consequences for receiving negative feedback, unlike teachers in the studies by Iyamu and Aduwa-Oglebaen (2005) and Yusuf et al. (2010), where junior teachers could lose their jobs due to negative feedback. 
When asked whether SET should be used for other purposes such as promotion and tenure, all of the teachers offered conditional agreement. They agreed that SET could be used for summative evaluations provided that it be used alongside other evaluation methods:

I think it should be taken into consideration because we spent a lot of time with the students, and then we interact with the students, so students could have [a] part [in] assessing our performance. (Tony)

According to Susan, 'one of the indicators of teacher performance came from the student evaluation'. However, Jane believed that several other evaluation tools should be considered when a teacher's career is at stake:

If the result of the questionnaire affect[s] the teacher's career in the future...I think, to avoid that, there must be another layer of evaluation from the institution to reevaluate the result of the questionnaire. For example, if the evaluation is so bad, they need to give the opportunity to the teachers to justify what they have been doing and what is happening actually. So that should be fair.

More importantly, the teachers mentioned that the institution should ensure the confidentiality of student feedback results and provide teachers with the necessary supports:

If you are talking about teacher evaluation like improvement for themselves, for their reflection, then I don't think it's necessarily to publish it to the other teachers or to the students. But, if it is for the evaluator, for [an] external evaluator, you know, for job promotion, I think there are also certain rules about publishing the evaluation of teacher performance in one institution. I don't think you can publish it...openly to everyone. I think there should be limits if you want to publish the evaluation. (Martha)

All the teachers believed that SET results should be kept confidential and distributed only to the evaluated teachers and their superiors, such as the heads of the English department or their study programme. This finding is similar to a study by Beran and Rokosh (2009) where teachers felt confidentiality was paramount. Hence, the university has an important role in ensuring confidentiality and teachers' ownership of the programme (Cohen \& Mays, 1981).

The teachers under study offered various views regarding what supports the institution should provide them. Tony, a junior teacher, recommended that the institution facilitate knowledge transfers from more experienced teachers to 
junior teachers. Tony said, "Teachers might also need training or help from other colleagues who are more experienced, and this kind of ability should be given to teachers." In fact, developing teachers' professional skills through training is an important outcome of collecting student feedback (OECD, 2009).

On the other hand, Martha asserts that teachers should be competent to respond to student feedback and adjust their teaching methods. Still, she suggests the institution provide expert consultations in certain circumstances:

Unless there are plenty of non-potential [i.e. unskilled] teachers hired by the institution, and most of the student evaluation[s] of teaching are negative, and...for instance, it has been done in a tricycle, and the evaluation still negative, then I think the institution should do something about it - maybe creating consultation department.

Interestingly, both Susan and Jane commented on the institution's role in providing teachers with assistance during the pandemic. As COVID-19 affected countries worldwide, fear of the deadly virus necessitated tremendous changes in the educational sector. During this unprecedented time, educators had to transition to online instruction regardless of their willingness or preparedness (Lemoine \& Richardson, 2020; McCormack et al., 2021). In this institution, during the early transition to teaching and learning online, many teachers felt anxious and stressed about delivering lessons online and creating teaching materials that support students' learning while away from campus. Susan and Jane discussed how the institution provided additional support for teachers to help them develop creative teaching materials and teach online effectively using the flipped learning method.

Susan mentioned the institution played its role well, responding to the unprecedented situation aptly by developing a science, technology, engineering and mathematics (STEM) unit. According to Susan, this unit 'help[ed] teachers develop their classroom management, teaching method[s] and methods for handling students' problems due to the online learning'. During this challenging time, the institution seems to have fulfilled its role of 'provid[ing] optimal favourable conditions to promote quality learning in students' (Tam, 2001, p. $53)$.

During the transition to online learning, some students shared their difficulty understanding the lessons and inability to join the online classes due to poor Internet connections. Jane, who happens to be a member of the STEM 
team, commented that the university responded quickly to student feedback during the pandemic:

The institution collected data and responded to them. Now we have a STEM unit. So, one of the passions [i.e. STEM purposes] is to provide trainings and workshops for teachers. So, this unit facilitates teachers to meet what the students actually need in online learning. So, for examples, how to create an interesting video, how to meet this kind of category of video, how to use [a] Zoom conference interestingly. So, that is the role of the institution, I think, especially in responding to student feedback and facilitat[ing] the teachers to meet the students' needs or feedback.

Although Jane did not explain how the university responded to students' difficulty accessing the Internet, she offered examples of institutional support to help teachers make their lessons easier for students to understand.

\section{CONCLUSIONS}

Overall, all the English teachers interviewed in this study regard SET positively. They are open-minded and welcome constructive criticism. They perceive negative feedback as opportunities for self-reflection that enable them to adjust their teaching approaches. For example, some teachers made their slideshows more attractive and their classes more interactive, while others slowed their pace while speaking English to help students understand them. Further, the teachers used their discretion to decide when to incorporate student feedback and make sensible changes. The main reason for teachers' positive attitudes is their belief that the students and assessment tools are credible. The teachers believe that validity and reliability are important factors in the trustworthiness of the instrument.

The teachers also believe that, as recipients of their teaching, students are capable of assessing teaching effectiveness. Moreover, they believe that the instrument used to collect student feedback is credible because the questions posed to students are not beyond their understanding and remain objective while assessing the teaching and learning process and materials. Using SET results solely for formative purposes also contributed to the teachers' positive perceptions. However, institutions should prepare teachers when SET results are used for accountability purposes, such as in decisions about a teacher's tenure or promotion. Institutions can prepare teachers through socialisation and by 
providing professional development programmes such as training sessions on how to deal with student feedback, addressing students' needs and improving instructors' teaching skills.

Although the teachers are confident that they can respond to student feedback, the challenges of teaching and learning in a university are dynamic, especially in light of the COVID-19 pandemic, which became a global issue in early 2020 (WHO, 2020). COVID-19 greatly disrupted higher education since universities have had to close their doors, stop face-to-face interactions, and rapidly transition teaching, learning, and assessments onto a digital platform (Lemoine \& Richardson, 2020; McCormack et al., 2021; Melnyk et al., 2020). Some scholars found that teachers were working under pressure due to the workfrom-home environment, as working from home creates challenges for teachers with familial responsibilities who must manage their time between domestic roles, teaching and researching (Neuwirth et al., 2020; Watermeyer et al., 2020). Therefore, universities must be resilient, adapting to new conditions and evolving while maintaining their core functions (Weller \& Anderson, 2013). During the COVID-19 pandemic, institutional support is essential to help teachers remain motivated and perform their responsibilities.

An institution can keep teachers motivated to use SET feedback for improvement by assuring confidentiality, providing expert consultations when needed, giving them ownership of the feedback and including them in the SET programme planning (Cohen \& Mays, 1981). Including teachers in the development of the SET questionnaires may improve the reliability and validity of the evaluation tool while also training teachers to design SET questionnaires appropriately. Further, providing expert consultation is important to help teachers commit to improving their teaching (Kulik, 2001; Murray, 1987). However, granting teachers the autonomy to decide what student feedback requires addressing is necessary to give teachers ownership of the feedback (Marsh \& Roche, 1993). Finally, institutional support is important to encourage student participation, motivate students to give honest responses (Clayson \& Haley, 2011) and ensure that student feedback is taken seriously (Richardson, 2005) by prompting teachers to act upon the student feedback (Seldin, 1997).

The institution's responsibility to collect SET responses promptly is important so that teachers have adequate time to respond and adjust their teaching practices for improvement (Svinicki, 2001). This may prevent students from being disappointed should teachers, for any reason, fail to act upon SET 
results (Kember et al., 2002). Overall, an institution should support teachers to ensure that they have the necessary skills and resources to act upon their SET results. Among other interventions, conducting regular professional development training sessions, monitoring teachers' performance and granting awards for good teaching may help improve teachers' skills and professionalism.

Nevertheless, this study's findings cannot be generalised to other Indonesian teachers and higher education institutions due to its limitations. For example, this study had few participants, all of whom are English teachers. Moreover, the teacher-participants originate from only one of Indonesia's 4,581 higher education institutions (PDDikti, 2021). Finally, considering the increasing issues related to online teaching, learning and assessment, further research may investigate university teachers' perceptions of student evaluation of online teaching, learning and assessment.

\section{REFERENCES}

Alsabahi, R. (2020). Problematizing student evaluation of teaching in Saudi Arabia: Merits, demerits and impacts on performance. In S. Troudi (Ed.), Critical issues in teaching english and language education (pp. 373-400). Palgrave Macmillan, Cham. https://doi.org/10.1007/978-3-030-53297$0 \_15$

Arthur, L. (2009). From performativity to professionalism: Lecturers' responses to student feedback. Teaching in Higher Education, 14(4), 441-454. https://doi.org/10.1080/13562510903050228

Badri, M. A., Abdulla, M., Kamali, M. A., \& Dodeen, H. (2006). Identifying potential biasing variables in student evaluation of teaching in a newly accredited business program in the UAE. Student Evaluation of Teaching, 20(1), 43-59. https://doi.org/10.1108/09513540610639585

Ballantyne, R., Borthwick, J., \& Packer, J. (2000). Beyond student evaluation of teaching: Identifying and addressing academic staff development needs. Assessment \& Evaluation in Higher Education, 25(3), 221-236. https://doi.org/10.1080/713611430

BAN-PT. (2019). Akreditasi program studi:Matriks penilaian laporan evaluasi diri dan laporan kinerja program studi [Study program accreditation: Assessment metrics for the self-evaluation report and performance report of study

programs]. https://www.banpt.or.id/wp- 
content/uploads/2019/10/Lampiran-6e-PerBAN-PT-5-2019-tentang-IAPSMatriks-Penilaian-Program-Sarjana-Terapan-1.pdf

Beran, T. N., \& Rokosh, J. L. (2009). Instructors ' perspectives on the utility of student ratings of instruction. Instructional Science, 37, 171-184. https://doi.org/10.1007/s11251-007-9045-2

Boring, A. (2016). Gender biases in student evaluations of teaching. Journal of Public Economics, 145, 27-41. https://doi.org/10.1016/j.jpubeco.2016.11.006

Bryman, A. (2008). Social research methods ( ${ }^{\text {rd }}$ ed.). Oxford University Press.

Cain, J., Stowe, C. D., Ali, D., \& Romanelli, F. (2019). How faculty recognized for teaching excellence interpret and respond to student ratings of teaching. American Journal of Pharmaceutical Education, 83(4), 565-573. https://doi.org/10.5688/ajpe6680

Chan, C. K. Y., Luk, L. Y. Y., \& Zeng, M. (2014). Teachers' perceptions of student evaluations of teaching. Educational Research and Evaluation, 20(4), 275289. https://doi.org/10.1080/13803611.2014.932698

Clayson, D. E., \& Haley, D. A. (2011). Are students telling us the truth? A critical look at the student evaluation of teaching. Marketing Education Review, 21(2), 101-112. https://doi.org/10.2753/MER1052-8008210201

Coffey, M., \& Gibbs, G. (2001). The evaluation of the student evaluation of educational quality questionnaire SEEQ in UK higher education. Assessment \& Evaluation in Higher Education, 26(1), 89-93. https://doi.org/10.1080/02602930020022318

Cohen, P. A., \& Mays, E. R. (1981). Using student-rating feedback to improve college teaching. California Journal of Teacher Education, 8(4), 27-36.

Debroy, A., Ingole, A., \& Mudey, A. (2019). Teachers' perceptions on student evaluation of teaching as a toll for faculty development and quality assurance in medical education. Journal of Education and Health Promotion, 8, 1-7. https://doi.org/10.4103/jehp.jehp_47_19

Dicker, R., Garcia, M., Kelly, A., \& Mulrooney, H. (2019). What does "quality" in higher education mean? Perceptions of staff, students and employers. Studies in Higher Education, 44(8), 1425-1441. https://doi.org/10.1080/03075079.2018.1445987

Emery, C. R., Kramer, T. R., \& Tian, R. G. (2003). Return to academic standards: A critique of student evaluations of teaching effectiveness. Quality 
336 TEFLIN Journal, Volume 32, Number 2, July 2021

Assurance in Education, 11(1), 37-46. https://doi.org/10.1108/09684880310462074

Flodén, J. (2017). The impact of student feedback on teaching in higher education. Assessment \& Evaluation in Higher Education, 42(7), 10541088. https://doi.org/10.1080/02602938.2016.1224997

Gaus, N., \& Hall, D. (2016). Performance indicators in Indonesian universities: The perception of academics. Higher Education Quarterly, 70(2), 127-144. https://doi.org/10.1111/hequ.12085

Green, D. (1994). What is quality in higher education? Concepts, policy and practice. In D. Green (Ed.), What is quality in higher education? (pp. 1132). The SRHE and Open University Press.

Grimard, C. M., Gates, B., \& Seldin, P. (2018). Modeling learning through experience: Using student feedback teams to continuously improve teaching. Developments in Business Simulation and Experiential Learning, 45 , 199-205.

https://journals.tdl.org/absel/index.php/absel/article/view/3164

Hammonds, F., Mariano, G. J., Ammons, G., \& Chambers, S. (2017). Student evaluations of teaching: Improving teaching quality in higher education. Perspectives: Policy and Practice in Higher Education, 21(1), 26-33. https://doi.org/10.1080/13603108.2016.1227388

Harvey, L., \& Green, D. (1993). Defining quality. Assessment \& Evaluation in Higher Education, 18(1), 9-26. https://doi.org/10.1080/ 0260293930180102

Harvey, L., \& Knight, P. T. (1996). Transforming higher education. SRHE and Open University Press.

Harvey, L., \& Newton, J. (2004). Transforming quality evaluation. Quality in Higher Education, 10(2), 149-165. https://doi.org/10.1080/1353832042000230635

Hedges, M. R., \& Webber, D. J. (2014). Using student evaluations to improve individual and department teaching qualities. Research in Post-Compulsory Education, 19(3), 323-339. https://doi.org/10.1080/13596748.2014.920584

Hendry, G. D., \& Dean, S. J. (2002). Accountability, evaluation of teaching and expertise in higher education. International Journal for Academic Development, 7(1), 75-82. https://doi.org/10.1080/13601440210156493 
Hornstein, H. A. (2017). Student evaluations of teaching are an inadequate assessment tool for evaluating faculty performance. Cogent Education, 4(1), 1-8. https://doi.org/10.1080/2331186X.2017.1304016

Huisman, J., \& Currie, J. A. N. (2004). Accountability in higher education: Bridge over troubled water? Higher Education, 48, 529-551. https://doi.org/10.1023/B:HIGH.0000046725.16936.4c

Iyamu, E. O. S., \& Aduwa-Oglebaen, S. E. (2005). Lecturers' perception of student evaluation in Nigerian Universities. International Education Journal, 6(5), 619-625. https://files.eric.ed.gov/fulltext/EJ855015.pdf

Kai, J. (2009). A critical analysis of accountability in higher education. Chinese Education \& Society, 42(2), 39-51. https://doi.org/10.2753/CED10611932420204

Kember, D., Leung, D. Y. P., \& Kwan, K. P. (2002). Does the use of student feedback questionnaires improve the overall quality of teaching? Assessment \& Evaluation in Higher Education, 27(5), 411-425. https://doi.org/10.1080/0260293022000009294

Kogan, L. R., Schoenfeld-Tacher, R., \& Hellyer, P. W. (2010). Student evaluations of teaching perceptions of faculty based on gender position and rank. Teaching in Higher Education, 15(6), 623-636. https://doi.org/10.1080/13562517.2010.491911

Krautmann, A. C., \& Sander, W. (1999). Grades and student evaluations of teachers. Economics of Education Review, 18(1999), 59-63.

Kulik, J. A. (2001). Student ratings: Validity, utility, and controversy. In P. C. Abrami, M. Theall, \& L. A. Mets (Eds.), The student ratings debate: Are they valid? How can we best use them? New Directions for Institutional Research (pp. 9-25). Jossey-Bass, A Publishing Unit of John Wiley \& Sons, Inc. https://doi.org/10.1002/ir.1

Lemoine, P. A., \& Richardson, M. D. (2020). Planning for higher education institutions: Chaos and the COVID-19 pandemic. Educational Planning, 27(3), 43-57. https://files.eric.ed.gov/fulltext/EJ1279907.pdf

Lynch, M. W. (2019). Teachers' experiences of student feedback: A view from a department of social work in Sweden. Aotearoa New Zealand Social Work, 31(2), 57-63. https://doi.org/10.11157/anzswj-vol31iss2id637

Maiyo, J. K. (2020). Perceptions of lecturers on students-course evaluations in universities in Kenya: A case study of Kibabii University. African 
338 TEFLIN Journal, Volume 32, Number 2, July 2021

Multidisciplinary Journal of Research (AMJR), 38-53. http://41.89.175.45/handle/123456789/1008

Marsh, H. W., \& Roche, L. (1993). The use of students' evaluations and an individually structured intervention to enhance university teaching effectiveness. American Educational Research Journal, 30(1), 217-251. https://doi.org/10.3102/00028312030001217

McCormack, T. J., Lemoine, P. A., Waller, R. E., \& Richardson, M. D. (2021). Global higher education: Examining response to the COVID-19 pandemic using agility and adaptability. Journal of Education and Development, 5(1), 10-16. https://doi.org/10.20849/jed.v5i1.848

Melnyk, Y. B., Pypenko, I. S., \& Maslov, Y. V. (2020). COVID-19 pandemic as a factor revolutionizing the industry of higher education. Rupkatha Journal on Interdisciplinary Studies in Humanities, 12(5), 1-6. https://doi.org/10.21659/RUPKATHA.V12N5.RIOC1S19N2

Mertens, E., \& Prosser, M. (1998). What constitutes high quality teaching and learning and how to assure it. Quality Assurance in Education, 6(1), 28-36. https://doi.org/10.1108/09684889810200368

Miles, M. B., \& Huberman, A. M. (1994). Qualitative data analysis (2 ${ }^{\text {nd }}$ ed.). SAGE Publications Ltd.

Moore, S., \& Kuol, N. (2005). Students evaluating teachers: Exploring the importance of faculty reaction to feedback on teaching. Teaching in Higher Education, 10(1), 57-73. https://doi.org/10.1080/1356251052000305534

Murray, H. G. (1987, April 20-25). Impact of student instructional ratings on quality of teaching in higher education [Paper presentation]. The Annual Meeting of the American Educational Research Association, Washington, DC, USA. https://files.eric.ed.gov/fulltext/ED284495.pdf

Nasser, F., \& Fresko, B. (2002). Faculty views of student evaluation of college teaching. Assessment and Evaluation in Higher Education, 27(2), 187-198. https://doi.org/10.1080/02602930220128751

Neumann, R. (2000). Communicating student evaluation of teaching results: Rating interpretation guides (RIGs). Assessment \& Evaluation in Higher Education, 25(2), 121-134. https://doi.org/10.1080/02602930050031289

Neuwirth, L. S., Jović, S., \& Mukherji, B. R. (2020). Reimagining higher education during and post-COVID-19: Challenges and opportunities. Journal of Adult and Continuing Education, O(0), 1-16. https://doi.org/10.1177/1477971420947738 
OECD. (2009, December 1-2). Teacher evaluation: A conceptual framework and examples of country practices [Paper presentation]. OECD-Mexico Workshop "Towards a Teacher Evaluation Framework in Mexico: International Practices, Criteria and Mechanisms", Mexico City, Mexico. https://www.academia.edu/4474610/Teacher_Evaluation_A_Conceptual_F ramework_and_examples_of_Country_Practices

Ory, J. C. (2000). Teaching evaluation: Past, present, and future. Evaluating Teaching in Higher Education, 13-18. https://doi.org/10.1002/t1.8302

PDDikti. (2021). PDDikti dalam angka [PDDikti in numbers]. Pangkalan Data Pendidikan Tinggi Kemdikbud. https://pddikti.kemdikbud.go.id/

Richardson, J. T. E. (2005). Instruments for obtaining student feedback: A review of the literature. Assessment \& Evaluation in Higher Education, 30(4), 387 415. https://doi.org/10.1080/02602930500099193

Scheerens, J., Glas, C., \& Thomas, S. M. (2003). Educational evaluation, assessment, and monitoring. Swets \& Zeitlinger B. V.

Seldin, P. (1997). Using student feedback to improve teaching. In D. DeZure (Ed.), To improve the Academy (Vol. 16, pp. 335-346). https://digitalcommons.unl.edu/podimproveacad/393

Shevlin, M., Banyard, P., Davies, M., \& Griffiths, M. (2000). The validity of student evaluation of teaching in higher education: Love me, love my lectures? Assessment \& Evaluation in Higher Education, 25(4), 397-405. https://doi.org/10.1080/713611436

Sofyan, M., Barnes, M., \& Finefter-Rosenbluh, I. (2021). Teacher effectiveness in Asian higher education contexts: A systematic review. Teaching in Higher Education, O(0), 1-25. https://doi.org/10.1080/13562517.2021. 1952567

Spiller, D., \& Ferguson, P. (2011). Student evaluations: Do lecturers value them and use them to engage with student learning needs? http://usir.salford.ac.uk/16999/

Spooren, P., \& Mortelmans, D. (2006). Teacher professionalism and student evaluation of teaching: Will better teachers receive higher ratings and will better students give higher ratings? Educational Studies, 32(2), 201-214. https://doi.org/10.1080/03055690600631101

Svinicki, M. D. (2001). Encouraging your students to give feedback. New Directions in Teaching and Learning: Special Issue: Techniques and Strategies for Interpreting Student Evaluations, 87, 17-24. https://doi.org/10.1002/t1.24 
Tam, M. (2001). Measuring quality and performance in higher education. Quality in Higher Education, 7(1), 47-54. https://doi.org/10.1080/13538320120045076

Tracy, S. J. (2013). Qualitative research methods: Collecting evidence, crafting analysis, communicating Impact. John Wiley \& Sons, Ltd.

Ulker, N. (2021). How can student evaluations lead to improvement of teaching quality? A cross-national analysis. Research in Post-Compulsory Education, 26(1), 19-37. https://doi.org/10.1080/13596748.2021.1873406

Usher, R. (1996). A critique of the neglected epistemological assumptions of educational research. In D. Scott \& R. Usher, Understanding educational research (pp. 9-32). Routledge.

Watermeyer, R., Crick, T., Knight, C., \& Goodall, J. (2020). COVID-19 and digital disruption in UK universities: Afflictions and affordances of emergency online migration. Higher Education, 81, 623-641. https://doi.org/10.1007/s10734-020-00561-y

Weller, M., \& Anderson, T. (2013). Digital resilience in higher education. European Journal of Open, Distance and e-Learning, 16(1), 53-66. https://doi.org/10.5860/choice.51-2973

WHO. (2020). WHO Director-General's opening remarks at the media briefing on COVID-19 - 11 March 2020. World Health Organization. https://www.who.int/director-general/speeches/detail/who-directorgeneral-s-opening-remarks-at-the-media-briefing-on-covid-19---11march-2020

Wong, W. Y., \& Moni, K. (2014). Teachers perceptions of and responses to student evaluation of teaching purposes and uses in clinical education. Assessment \& Evaluation in Higher Education, 39(4), 397-411. https://doi.org/10.1080/02602938.2013.844222

Yao, Y., \& Grady, M. L. (2006). How do faculty make formative use of student evaluation feedback?: A multiple case study. Journal of Personnel Evaluation in Education, 18(2), 107-126. https://doi.org/10.1007/s11092006-9000-9

Yusuf, A., Ajidagba, U. A., Agbonna, S. A., \& Olumorin, C. O. (2010, February 9-11). University teachers' perception of the effects of students evaluation of teaching on lecturers instructional practices in Nigeria [Paper presentation]. 1st International Conference of Collaboration of Education Faculties in West Africa (CEFWA), University of Ilorin, Ilorin, Nigeria. 
Silalahi, English Teachers' Perceptions of SET in an Indonesian University 341

https://www.kwcoeilorin.edu.ng/publications/staff_publications/abdulrahe em_yusuf/University-Teachers-Perception-of-the-Effects-of-StudentsEvaluation-of-Teaching-on-Lecturers-Instructional-Practices-inNigeria.pdf

Zabaleta, F. (2007). The use and misuse of student evaluations of teaching. Teaching in Higher Education, 12(1), 55-76. https://doi.org/10.1080/13562510601102131 